\title{
Sinonasal inverted papillomas: recurrence, and synchronous and metachronous malignancy
}

\author{
S Mirza, P J Bradley, A Acharya, M Stacey, N S Jones
}

\begin{abstract}
Introduction: Inverted papillomas are relatively rare, benign epithelial tumours of the nasal cavity which generate considerable interest because they are locally aggressive, have a tendency to recur and are associated with malignancy.

Aims: To review our experience of the management of inverted papillomas, and to review the literature in order to evaluate recurrence rates, rates of synchronous and metachronous carcinoma, and outcomes of treatment, both endoscopic and conventional.

Methods: We retrospectively reviewed all cases of inverted papilloma that presented to our unit, a tertiary referral centre, over a 20-year period from 1985 to 2005. A Medline review of the literature was performed to identify published case series of inverted papillomas. We undertook a critical analysis of the literature.

Results: We treated 65 patients with inverted papilloma over the 20-year period, with a mean follow up of five years (range one to 20 years). Fifty-eight patients initially underwent nasal biopsy, often with polypectomy. Thirty-six had endoscopic surgery, with five (14 per cent) suffering recurrence, whilst 16 had a lateral rhinotomy and medial maxillectomy, of which four (25 per cent) suffered a recurrence. Seven septal inverted papillomas required local resection, with no subsequent recurrences. There were seven (11 per cent) synchronous and two metachronous malignancies.

Sixty-three case series with adequate data were identified from the literature. There were 163 ( 7.1 per cent) cases of synchronous carcinoma, out of 2297 cases. Metachronous carcinomas were reported in 74 out of 2047 cases, representing a transformation rate of 3.6 per cent. However, the true population base for these figures is uncertain, given that many series were reported from tertiary centres, where recurrent and problematic cases are likely to be over-represented. The recurrence rates were 12.8 per cent for endoscopic procedures, 17.0 per cent for lateral rhinotomy with medial maxillectomy, and 34.2 per cent for limited resections such as nasal polypectomy and Caldwell-Luc approaches. No significant association between atypia or dysplasia and recurrence or malignant transformation was found. The mean time taken to develop a metachronous carcinoma was 52 months (range six to 180 months). The estimated malignant potential for recurrent disease was up to 11 per cent.

Conclusion: Patients with inverted papilloma should undergo thorough surgery to remove all mucosal disease, most probably by the endoscopic, endonasal route when complete resection is possible. Cases demonstrating atypia or dysplasia may be treated by the endoscopic route. Recurrent disease and metachronous carcinoma can develop after a prolonged period of time. Long-term follow up is recommended to detect recurrence, as disease can become quite extensive before it becomes symptomatic.
\end{abstract}

Key words: Inverted Papilloma; Paranasal Sinus Neoplasm; Endoscopy; Minimally Invasive Surgery

\section{Introduction}

Inverted papillomas most commonly arise from the lateral wall of the nasal cavity, with local extension to the paranasal sinuses which may extend to the nasopharynx. More rarely, they may traverse the cribriform plate or orbit, particularly if they are associated with malignancy. Infrequently, they arise from the nasal septum, ${ }^{1}$ although the histology of these lesions warrants a critical analysis as to whether they are truly inverted or not. The term inverted papilloma describes the histological appearance of the epithelium as inverting into the stroma, with a distinct and intact basement membrane that separates and defines the epithelial component from the underlying connective tissue stroma. ${ }^{2}$

The tumour may also be associated with atypia, dysplasia and carcinoma in situ, as well as with frank squamous cell carcinoma. An inverted 
papilloma with synchronous carcinoma occurs when there is no history of a previously resected papilloma. The carcinoma may arise from the papilloma itself or it may be found as a separate lesion. ${ }^{3}$ An inverted papilloma with metachronous carcinoma develops at the site of a previously benign inverted papilloma. The numerous publications on inverted papilloma differ widely in their reported incidence of associated carcinoma, which ranges from $0^{4}$ to 53 per cent. ${ }^{5}$

Most surgeons agree that recurrence is the result of either incomplete removal of the original tumour or disease developing from predisposed mucosa, both of which occur more often with limited resections. ${ }^{6}$ Recurrence rates of up to 71 per cent have been reported following conservative surgery (polypectomy, Caldwell-Luc or local excision). ${ }^{7}$

Historically, the 'gold standard' has been an external approach with a medial maxillectomy via a lateral rhinotomy or midfacial degloving procedure. ${ }^{6,8}$ This accomplishes several goals, including: providing a specimen to rule out synchronous malignancy; reducing the recurrence rate and the need for repeat procedures; and reducing the possibility of progression to a metachronous malignancy. Vrabec $(1994)^{6}$ reported a recurrence rate of only 2 per cent after lateral rhinotomy with a modified Weber-Ferguson incision, with a mean follow up of 8.9 years. Recently, however, endoscopic resection has been increasingly favoured because it obviates the morbidity of an external approach. ${ }^{9}$ Endoscopes have made complete endonasal tumour resection possible, even in unfavourable sites such as the anterior wall of the maxillary sinus. Alternatively, some surgeons have combined the endonasal operation with an external procedure. ${ }^{10}$ Tomenzoli et al. $(2004)^{11}$ described no recurrences in their series of 47 inverted papillomas treated endoscopically, with a mean follow up of 55 months.

The aim of this study was to review our management of inverted papillomas, particularly with regard to the outcomes of different surgical techniques. In addition, we assessed our recurrence rates, as well as the incidences of synchronous and metachronous malignancy. We also reviewed the world literature, critically analysing these features.

\section{Methods}

We retrospectively reviewed all cases of inverted papilloma which presented to the University Hospital, Nottingham (a tertiary referral centre), over a 20-year period from 1985 to 2005. In particular, we assessed the demographics, management, surgical technique and outcome, including recurrence and association with malignancy.

A Medline review of the literature was performed to identify case series of inverted papillomas published from 1966 onwards. When a single centre had generated more than one case series from overlapping time frames, data from the most recent series were used.

The pathological criteria for inverted papilloma became standardised in 1975 . It has been suggested that reports of malignancy arising in inverted papilloma prior to this should be reviewed with caution, ${ }^{12}$ and we considered the implication of this in our case selection. Schneiderian papillomas can be classified into inverted, fungiform or cylindrical cell variant. The inverted type tends to be associated with local invasion and carcinoma. ${ }^{13}$ We critically analysed the literature to try to differentiate synchronous from metachronous carcinomas.

\section{Results}

Between 1985 and 2005, we managed 65 patients with inverted papilloma. Patients comprised 53 men and 12 women, with a mean age of 50 years and an age range of $17-76$ years. The mean follow up was five years, with a range of one to 20 years. Fifty-eight cases of inverted papilloma arose from the lateral nasal wall; all 58 underwent simple polypectomy, with histological analysis showing inverted papilloma. Eight cases had disease extending into the frontal sinus, and four cases featured very extensive disease that was bilateral. Interestingly, 37 cases of nasal septal lesions were reported as having some inverted papilloma features on histological analysis; however, on review, only seven were true inverted papillomas, whilst the rest were transitional papillomas that were so profuse in part and rolled upon themselves that they had been misinterpreted as inverted.

The results of surgical management are shown in Table I. In the endoscopic group, 15 patients had undergone more than one previous nasal polypectomy and one patient had undergone a previous lateral rhinotomy. In the lateral rhinotomy group, three patients had previously undergone more than one nasal polypectomy. The majority of previous procedures were performed at other institutions and are summarised in Table II.

Of the 65 patients with inverted papilloma, seven (11 per cent) were found to have synchronous squamous cell carcinomas. Six of these underwent a lateral rhinotomy with medial maxillectomy as well as post-operative radiotherapy; four remained disease free after follow up for, variously, one year (this patient also underwent a concurrent craniofacial approach) and six, nine and 16 years. One patient had a local recurrence after four years and one patient died of intracranial involvement after two years. The seventh patient with a carcinoma had disease that involved the septum, which was locally excised with no subsequent radiotherapy and no recurrence after a seven-year follow up.

There were two cases of metachronous carcinoma in our series. One patient had undergone an original nasal polypectomy 22 years previously, showing inverted papilloma, and had then undergone three further polypectomies and an intranasal ethmoidectomy. Thirteen years later, the patient had presented to us with carcinoma, for which he underwent a lateral rhinotomy, medial maxillectomy and subsequent radiotherapy. He showed no signs of recurrence after six years. 
TABLE I

SURGICAL RESULTS FOR INVERTED PAPILLOMA*, UNIVERSITY OF NOTTINGHAM, 1985-2005

\begin{tabular}{|c|c|c|c|c|c|}
\hline \multirow[t]{2}{*}{ Procedure } & \multirow[t]{2}{*}{$n$} & \multicolumn{3}{|c|}{ Recurrences $(n)$} & \multirow[t]{2}{*}{ Comments } \\
\hline & & None & 1 & $>1$ & \\
\hline Intranasal polypectomy & $58^{\dagger}$ & 6 & 0 & 52 & $\begin{array}{l}1 \text { patient had } 4 \\
\text { polypectomies } \\
\text { (elsewhere), then } \\
\text { malignant transformation } \\
13 \text { yrs later }\end{array}$ \\
\hline Endoscopic sinus surgery & $36^{\dagger}$ & 32 & $\begin{array}{l}4 \text { localised (incl } 3 \text { with } \\
\text { extensive bilateral disease } \\
\& \text { av of } 6 \text { previous } \\
\text { procedures) }\end{array}$ & $\begin{array}{l}1 \text { patient had } 2 \text { previous } \\
\text { polypectomies, } 1 \\
\text { endoscopic procedure } \\
\text { then malignant } \\
\text { transformation } 3 \text { yrs later }\end{array}$ & \\
\hline Lateral rhinotomy & $16^{\ddagger}$ & 12 & 4 & 0 & $\begin{array}{l}3 \text { recurrences remained } \\
\text { clear after a further } \\
\text { endoscopic clearance, \& } \\
\text { the other after revision } \\
\text { lateral rhinotomy }\end{array}$ \\
\hline Septal lesion excision & 7 & 0 & 0 & 0 & \\
\hline
\end{tabular}

*Sixty-five cases. ${ }^{\dagger}$ All underwent polypectomy or biopsy; only six had no further sign of disease and no further surgery.

${ }^{\dagger}$ Six underwent endoscopic medial maxillectomy and dacryocystorhinostomy. ${ }^{*}$ Two had craniofacial resection, one had frontal sinus obliteration and one had resection of lateral nasal wall and lacrimal sac. Yrs = years; incl = including; av = average

The second patient with a metachronous carcinoma had undergone two intranasal polypectomies 10 and 9 years earlier for inverted papilloma. Three years after undergoing an endoscopic medial maxillectomy, this unfortunate 36-year-old woman presented to us with an infiltrating carcinoma that extended into the soft tissues of the nasal vestibule and upper lip as well as having bilateral neck metastases. She was advised to undergo chemoradiotherapy but elected to have primary surgery elsewhere.

Of the cases treated by us from first presentation, none went on to develop a metachronous malignancy.

Two patients had carcinoma in situ; both were treated by lateral rhinotomy and neither had any recurrence, after three years and six years. Two patients had moderate or severe dysplasia; one was treated by lateral rhinotomy, with no recurrence after 11 years, and the other underwent endoscopic sinus surgery, with no recurrence after one year.

TABLE II

PREVIOUS SURGERY IN INVERTED PAPILLOMA CASES*, UNIVERSITY OF NOTTINGHAM, 1985-2005

\begin{tabular}{lr}
\hline Before endoscopic sinus surgery & $n$ \\
1 biopsy & 6 \\
1 previous polypectomy & 14 \\
2 previous polypectomies & 9 \\
3 previous polypectomies & 2 \\
4 previous polypectomies & 3 \\
8 previous polypectomies & 1 \\
1 lateral rhinotomy & 1 \\
Before lateral rhinotomy & 5 \\
1 biopsy & 8 \\
1 previous polypectomy & 1 \\
2 previous polypectomies & 1 \\
4 previous polypectomies & 1 \\
5 previous polypectomies & \\
\hline
\end{tabular}

*Sixty-five cases.

\section{Literature review}

Sixty-three case series suitable for analysis were identified from the literature. Table III summarises the data. There was a total of 3058 cases. Eleven series found atypia, in a total of 88 cases out of 958. Nine series noted dysplasia, in 56 cases out of 454. Nine series found carcinoma in situ, in 14 cases out of 414. There were 163 (7.1 per cent) cases of synchronous carcinoma out of 2297 cases, the vast majority being squamous cell carcinomas. There were also cases of transitional cell carcinoma, adenocarcinoma, mucoepidermoid carcinoma and verrucous carcinoma. Metachronous carcinomas were reported in 75 cases out of 2047, representing a malignant transformation rate of 3.6 per cent. A number of series were vague about whether a carcinoma was synchronous or metachronous and these series were therefore excluded. Follow-up periods were variable, and in some series (particularly histopathological studies) were not detailed.

A total of 484 endoscopic procedures were performed, with 62 recurrences (12.8 per cent). There were 1025 external procedures involving a medial maxillectomy, with 174 recurrences (17.0 per cent). There were 600 limited transnasal procedures (such as a local resection, nasal polypectomy or Caldwell-Luc procedure), with 205 recurrences (34.2 per cent).

In the atypia group, 23 out of 55 cases suffered recurrence, but 13 of these occurred in a single series of 16 patients. ${ }^{14}$ Vrabec $^{6}$ detailed 17 patients with atypia who all underwent medial maxillectomy via a lateral rhinotomy, with only one recurrence (which was successfully cleared by a repeat lateral rhinotomy). Just one case of atypia in the literature was found to go on to develop carcinoma. ${ }^{15}$ In all the series examined, there were very few details given for cases with dysplasia. As far as we could tell, no carcinomas 
TABLE III

LITERATURE REVIEW OF INVERTED PAPILLOMA: CASE SERIES RESULTS

\begin{tabular}{|c|c|c|c|c|c|c|c|}
\hline Study \& year & $\begin{array}{c}\text { Cases } \\
(n)\end{array}$ & $\begin{array}{l}\text { Synch } \\
(n)\end{array}$ & $\begin{array}{c}\mathrm{ESS} \\
(n)\end{array}$ & Ext & Others & $\begin{array}{l}\mathrm{F} / \mathrm{U} \text { mean } \\
\text { (range) }\end{array}$ & MetCa \\
\hline $\begin{array}{l}\text { Abildgaard-Jensenand } \\
\text { \& Greisen } 1985^{30}\end{array}$ & 21 & 2 & & 15 & 4 & 3.5 y $(1-7)$ & 0 \\
\hline Barnes \& Bedetti $1984^{31}$ & 61 & 8 & & & & & \\
\hline Baruah \& Deka $2003^{9}$ & 6 & & 6 & & & $0.5-5 \mathrm{y}$ & 0 \\
\hline Benninger et al. $1991^{23}$ & 46 & 11 & & 20 & 14 & $45 \mathrm{~m}(2-10 \mathrm{y})$ & 0 \\
\hline Bielamowicz et al. $1993^{7}$ & 61 & 5 & & 20 & 34 & 4.3 y $(8 \mathrm{~m}-15 \mathrm{y})$ & 5 \\
\hline Buchwald \& Larsen $2005^{32}$ & 42 & & 42 & & & $37 \mathrm{~m}(9-69)$ & 0 \\
\hline Buchwald et al. $1995^{33}$ & 58 & 3 & 5 & 28 & & $\begin{array}{l}\text { ESS med } 2 \text { y }(0.5-4) \\
\text { Ext } 7 \text { y }(2 \mathrm{~m}-20 \mathrm{y})\end{array}$ & 1 \\
\hline Calcaterra et al. $1980^{8}$ & 34 & 1 & & 19 & & & 2 \\
\hline Chee \& Sethi $1999^{34}$ & 18 & & 18 & & & $32 \mathrm{~m}(18-62)$ & 0 \\
\hline Christensen \& Smith $1986^{13}$ & 32 & 6 & & & & & 3 \\
\hline Cummings \& Goodman $1970^{35}$ & 29 & 0 & & 7 & 22 & & \\
\hline Dolgin et al. $2000^{36}$ & 42 & 4 & & 17 & & & 1 \\
\hline Eavey $1985^{37}$ & 5 & 1 & & 4 & & 2.5 y $(2-5.5)$ & 0 \\
\hline Eggers et al. $2005^{38}$ & 93 & 8 & & & & & 4 \\
\hline Furuta et al. $1991^{39}$ & 26 & 5 & & & 26 & & 2 \\
\hline Hwang et al. $1998^{40}$ & 42 & 5 & & & 37 & & 1 \\
\hline Ingle et al. $1998^{41}$ & 68 & 1 & & & & & 9 \\
\hline Jardine et al. $2000^{26}$ & 89 & 2 & & 30 & 59 & $5 \mathrm{y}$ & 0 \\
\hline Kamel $1995^{42}$ & 17 & & 17 & & & $35 \mathrm{~m}(24-60)$ & 0 \\
\hline Kaufman et al. $2002^{21}$ & 34 & 2 & 17 & 17 & & & 1 \\
\hline Kaza et al. $2003^{43}$ & 51 & & 51 & & & $30 \mathrm{~m}(6-99)$ & \\
\hline Kelly et al. $1980^{44}$ & 18 & 0 & & & 18 & & 0 \\
\hline Klimek et al. $2000^{45}$ & 55 & 3 & 33 & 22 & & & 0 \\
\hline Kraft et al. $2003^{10}$ & 34 & 4 & 26 & 12 & & $62 \mathrm{~m}(0-141)$ & 0 \\
\hline Kristensen et al. $1985^{46}$ & 83 & 4 & & 57 & 21 & $8.7 \mathrm{y}, 10.4 \mathrm{y}$ & 3 \\
\hline Lasser et al. $1976^{47}$ & 17 & 2 & & & 17 & $6 \mathrm{~m}-14 \mathrm{y}$ & 2 \\
\hline Lawson et al. $2003^{1}$ & 160 & 7 & 30 & 112 & & $46 \mathrm{~m}(10-144)$ & 4 \\
\hline Lesperance \& Esclamado $1995^{12}$ & 51 & 6 & & & & & 8 \\
\hline Llorente et al. $2003^{48}$ & 27 & 0 & 27 & & & 5 y $(2-8)$ & 0 \\
\hline Lund $2000^{49}$ & 37 & & 13 & 24 & & $45 \mathrm{~m}(12-90)$ & 0 \\
\hline Majumdar \& Beck $1984^{50}$ & 43 & 3 & & & & & 1 \\
\hline Mansell \& Bates $2000^{4}$ & 43 & 0 & 31 & 12 & & $\begin{array}{l}\text { ESS } 4.1 \mathrm{y} \\
\text { Ext } 4.4 \mathrm{y}\end{array}$ & 0 \\
\hline McCary et al. $1994^{51}$ & 24 & 0 & 7 & 17 & & $19 \mathrm{~m}(5-38)$ & 0 \\
\hline Mickelson \& Nichols $1990^{52}$ & 23 & 1 & & 15 & & 4.7 y $(2 \mathrm{~m}-12 \mathrm{y})$ & 0 \\
\hline Mirza et al. $1999^{53}$ & 15 & 1 & & & 13 & $2-5 y$ & 0 \\
\hline Momose et al. $1980^{54}$ & 115 & 7 & & & & & \\
\hline Myers et al. $1990^{24}$ & 33 & 7 & & 23 & & 9.6 y $(3-16 y)$ & 0 \\
\hline Norris $1962^{55}$ & 29 & 1 & & & 29 & $6 y(2-11 y)$ & 1 \\
\hline Oberman $1964^{56}$ & 15 & 2 & & & 12 & & 1 \\
\hline Orvidas et al. $1999^{57}$ & 5 & 4 & & & & & 1 \\
\hline Outzen et al. $1991^{25}$ & 67 & 0 & & 48 & 8 & $34 \mathrm{~m}(6-37)$ & 1 \\
\hline Pelausa \& Fortier $1992^{22}$ & 35 & 0 & & 21 & & $3.4 \mathrm{y}(1 \mathrm{~m}-20 \mathrm{y})$ & 4 \\
\hline Phillips et al. $1990^{58}$ & 112 & & & 72 & 40 & $6.2 \mathrm{y}$ & \\
\hline Raveh et al. $1996^{29}$ & 56 & 4 & 9 & 18 & & $\begin{array}{l}\text { ESS } 26 \mathrm{~m} \\
\text { Ext } 7.5 \mathrm{y}\end{array}$ & 0 \\
\hline Ridolfi et al. $1977^{59}$ & 30 & & & & & & 0 \\
\hline Schlosser et al. $2001^{60}$ & 21 & 1 & 21 & & & $42 \mathrm{~m}$ & 0 \\
\hline Segal et al. $1986^{61}$ & 30 & 0 & & 10 & 20 & & 3 \\
\hline Smith \& Gullane $1987^{62}$ & 48 & 2 & & 11 & & & 1 \\
\hline Snyder \& Perzin $1972^{14}$ & 35 & 7 & & & 26 & $8 \mathrm{y}$ & 1 \\
\hline Stankiewicz \& Girgis $1993^{63}$ & 15 & & 15 & & & $3 \mathrm{y}$ & 0 \\
\hline Suh et al. $1977^{19}$ & 57 & 1 & & 30 & 24 & $5.9 \mathrm{y}$ & 3 \\
\hline Terzakis et al. $2002^{64}$ & 42 & 4 & & 38 & & & 0 \\
\hline Thorp et al. $2001^{65}$ & 53 & 1 & 2 & 41 & 10 & $\begin{array}{l}\text { ESS } 36 \mathrm{~m} \\
\text { Ext } 28 \mathrm{~m} \\
\text { Others } 49 \mathrm{~m}\end{array}$ & 3 \\
\hline Tomenzoli et al. $2004^{11}$ & 47 & & 47 & & & $55 \mathrm{~m}(30-132)$ & 0 \\
\hline Tufano et al. $1999^{66}$ & 33 & & 13 & & 20 & $12 \mathrm{~m}$ & 0 \\
\hline Vrabec $1994^{6}$ & 101 & 7 & 2 & 96 & & $8.9 \mathrm{y}$ & 1 \\
\hline Waitz \& Wigand $1992^{18}$ & 51 & & 35 & & 16 & $46 \mathrm{~m}(12-143)$ & 1 \\
\hline Weissler et al. $1986^{20}$ & 223 & 8 & & 126 & & & 3 \\
\hline Weiner et al. $1999^{67}$ & 82 & 8 & & & & & \\
\hline Woodson et al. $1985^{68}$ & 90 & 1 & & 2 & 71 & & 0 \\
\hline Wormald et al. $2003^{69}$ & 17 & & 17 & & & $40 \mathrm{~m}(9-98)$ & 0 \\
\hline Yamaguchi et al. $1979^{5}$ & 15 & 6 & & 13 & & & 2 \\
\hline Yoon et al. $2002^{17}$ & 96 & 9 & & 28 & 59 & $24-72 \mathrm{~m}$ & 2 \\
\hline
\end{tabular}

Synch = synchronous carcinoma; ESS = endoscopic sinus surgery; Ext = external approach (including medial maxillectomy); Others = limited procedure; $\mathrm{F} / \mathrm{U}=$ follow up; $\mathrm{MetCa}=$ metachronous carcinoma; $\mathrm{y}=$ years; $\mathrm{m}=$ months; med $=$ median 
were clearly reported as developing from a case of dysplasia.

For synchronous carcinomas, outcomes were only reported in 73 patients, of whom 28 (38 per cent) died of their disease. The time to death was given in 19 cases, with a mean of 26 months (range three to 120 months). Six cases died of an unrelated disease, and in 39 cases there were no signs of recurrence. The follow-up period in those who were disease free was reported in 25 cases, with a mean of 18 months (range zero to 180 months).

The outcomes of metachronous carcinomas were only given in 20 cases. Eight cases died of their disease. In seven cases, the time period to death was given, with a mean of 45 months (range 12-96 months). No signs of recurrence were reported in 12 cases. Ten of these had a reported follow-up period, with a mean of 65 months (range 12-120 months). The time to carcinoma development (i.e. the time from first presentation of the inverted papilloma to subsequent malignant transformation) was given in 20 cases, with a mean of 52 months (range six to 180 months). In seven cases of metachronous carcinoma, the cancer was reported to occur in the first recurrence after definitive treatment of the inverted papilloma. However, in nine cases of metachronous carcinoma, at least one recurrence of the inverted papilloma was reported before development of the carcinoma.

\section{Discussion}

Recurrence

Reported recurrence rates of inverted papilloma vary widely, ranging from 0 to 78 per cent. ${ }^{9}$ Recurrence of inverted papilloma may depend on a number of factors, including tumour location, extent, histology, multicentricity, method of removal, primary versus secondary resection, follow up and biological variability of the tumour. Of the aforementioned, the main factor in tumour recurrence is the thoroughness of removal. ${ }^{1}$ Most recurrences are thought to develop because of inadequate resection at the site of origin. ${ }^{16}$ Bielamowicz et al. $(1993)^{7}$ found a statistically significant difference in the recurrence rates of patients treated with a medial maxillectomy (20 per cent) compared with those treated with a conservative resection (47 per cent). This is borne out both in our personal experience and in our literature review, with limited transnasal procedures having a higher recurrence rate. The endoscopic sinus approach had a lower recurrence rate than the medial maxillectomy resection, but this most probably related to case selection. The completeness of removal appears to be the key aspect, not the approach. Recurrence occurring despite radical resection may be explained by the multicentric nature of the papilloma. ${ }^{10}$

Human papilloma virus has been implicated in causing inverted papilloma, and its deoxyribonucleic acid has been found in both the inverted papilloma and the cells of neighbouring, apparently normal mucosa. ${ }^{6}$ Removing a certain amount of the neighbouring, apparently normal, predisposed mucosa may be required to reduce the rate of recurrence. ${ }^{17}$ The more advanced the tumour, the greater the risk of recurrence. $^{10,18}$ Once an inverted papilloma has recurred, the risk of subsequent recurrence increases to up to 58 per cent. ${ }^{13}$

\section{Atypia}

In the series of Snyder and Perzin (1972), ${ }^{14}$ of 10 patients with marked atypia in areas of papillomatosis, five also demonstrated carcinoma elsewhere. These authors advocated a careful search for carcinoma in cases in which atypia is found. Previous studies have suggested that features of atypia may predispose to recurrence. ${ }^{14,19}$ However, more recent studies showed no correlation between the degree of atypia, or the mitotic index, and recurrence or transformation into carcinoma. ${ }^{13,20}$

\section{Dysplasia}

In a series featuring 23 cases of dysplasia, there was no apparent relationship between increased dysplasia and recurrence, although follow-up information was limited. ${ }^{21}$ Our review of the literature showed limited data, with no strong correlation between dysplasia and subsequent recurrence or malignant transformation. We therefore feel that inverted papilloma with atypia or dysplasia should be treated in the same way as benign disease.

\section{Carcinoma in situ}

The outcomes of 11 cases of carcinoma in situ were reported in the literature. There were no obvious recurrences, but three cases subsequently developed a carcinoma, with one patient dying after one year from metastases. ${ }^{22}$ Such patients should therefore be closely followed up.

\section{Synchronous carcinoma}

All submitted tissue should be serially sectioned and thoroughly searched for coexisting carcinoma. ${ }^{5}$ Our synchronous carcinoma rate of 11 per cent was similar to the overall rate of 7.1 per cent reported in the literature. Therefore, unilateral, apparently benign nasal polyps that may be inverted papillomas must be taken seriously. Inverted papillomas with synchronous carcinoma appear to arise at a later mean age than do their benign counterparts, tending to appear at 60 rather than 50 years of age. ${ }^{7}$

A study comparing the five-year survival rates of patients with sinonasal squamous cell carcinoma with and without inverted papilloma found respective rates of 70 and 30 per cent; this difference was statistically significant. ${ }^{23}$ Therefore, carcinoma associated with inverted papilloma carried a better prognosis. In our review of the literature, 28 (38 per cent) patients out of 73 died of their disease. Bone destruction may be associated with a poor prognosis. $^{24}$ In general, treatment consisted of radical surgery with post-operative radiotherapy. 6,24 
- This paper includes a retrospective review of 65 cases of inverted papilloma presenting to a UK tertiary referral centre over a 20-year period (1985-2005)

- Recurrence rates were $\mathbf{1 2 . 8}$ per cent for endoscopic procedures, 17.0 per cent for lateral rhinotomy with medial maxillectomy and 34.2 per cent for limited resections (such as nasal polypectomy and Caldwell-Luc approaches)

- Patients with inverted papilloma should undergo thorough surgery to remove all mucosal disease, most probably by the endoscopic endonasal route when complete resection is possible

- Long-term follow up is recommended to detect recurrence, as disease can become quite extensive before it becomes symptomatic

\section{Metachronous carcinoma}

Reported studies are often from tertiary referral centres, which attract problematic, recurrent and extensive cases and which therefore probably overestimate the true incidence of metachronous carcinoma in cases of inverted papillomas. ${ }^{25}$ The metachronous carcinoma rate of 3.6 per cent, from our review of the literature, may also be higher than the true value. Our series featured two metachronous carcinoma cases, but these were referred from other units after they had received surgery. None of our cases treated from first presentation went on to develop carcinoma. Many of the published series may feature metachronous cases with a similar background. On the other hand, relatively short follow-up periods may underestimate the incidence of metachronous malignancy. Jardine et al. $(2000)^{26}$ reported 89 cases of inverted papilloma outside a tertiary referral centre, with a mean follow up of five years, but observed no metachronous carcinomas.

Efforts to predict which cases of inverted papilloma will ultimately undergo malignant transformation have generally been unsuccessful. ${ }^{8}$ Hyams $(1971)^{15}$ found no correlation between the interval or the number of recurrences in the development of a malignancy. In a pathological study that included two metachronous carcinomas, Nielsen et al. $(1991)^{27}$ found that malignancy was associated with: bilateral inverted papilloma, a predominance of mature squamous epithelium, the presence of all three epithelial types (metaplastic squamous, mature squamous and cylindrical), severe hyperkeratosis, a mitotic index of two or more per high power field, absence of inflammatory polyps, an abundance of plasma cells, and an absence of neutrophils. Hyams $^{15}$ found that the chances of a malignancy developing in a recurrent inverted papilloma were less than 3-4 per cent.
The lack of detail in the literature prevents an accurate estimation, but a crude calculation can be performed. In the literature, in all the series giving a total of recurrences, there were 441 recurrences and 48 metachronous carcinomas. It may be calculated that 48 metachronous carcinomas occurred out of 441 recurrent inverted papillomas; it may therefore be estimated that 11 per cent $(48 / 441)$ of recurrent papillomas subsequently develop into a metachronous carcinoma. This is likely to be an overestimation, for the reasons mentioned above, and also because a proportion of metachronous malignancies will arise at the first recurrence rather than after a recurrence or recurrences of benign disease. Recurrent disease, in particular, should be treated with drilling of the underlying bone to make the complete removal of all diseased mucosa more likely.

\section{Follow up}

Most recurrences occur within the first two years after surgery, but 17 per cent can occur after more than five years, including 6 per cent after 10 years. $^{20}$ Inverted papillomas can recur after an apparent remission of many years, and recurrences can progress without significant symptoms, such that the disease may be advanced before patients seek attention. Some authors advocate a follow up of at least five years. ${ }^{10,28}$ However, in view of the possibility of late recurrence, and a mean time to the development of carcinoma of 52 months (range six to 180 months), life-long follow up (as advocated by some $)^{20,29}$ may be appropriate.

\section{Conclusion}

Based on careful scrutiny of the literature, the rates of synchronous and metachronous carcinomatous transformation of inverted papilloma are 7.1 and 3.6 per cent, respectively, although rates may be exaggerated due to a referral bias to tertiary centres. When complete resection is possible, patients should undergo thorough removal of all diseased mucosa, via the endoscopic endonasal route, together with thorough histological examination of all the resected specimen. Cases featuring atypia or dysplasia may also be treated by the endoscopic route. We estimate that up to 11 per cent of recurrent inverted papillomas may undergo malignant transformation. Recurrent disease and metachronous carcinoma can develop after a prolonged period of time and this can become extensive before becoming symptomatic. Life-long follow up is recommended.

\section{References}

1 Lawson W, Kaufman MR, Biller HF. Treatment outcomes in the management of inverted papillomas: an analysis of 160 cases. Laryngoscope 2003; 113:1548-56

2 Batsakis JG. Tumours of the Head and Neck, 2nd edn. Baltimore: Williams \& Wilkins, 1979;132-7

3 Kerschner JE, Futran ND, Chaney V. Inverted papilloma associated with squamous cell carcinoma and adenocarcinoma: case report and review of the literature. Am J Otolaryngol 1996;17:257-9

4 Mansell NJ, Bates GJ. The inverted Schneiderian papilloma: a review and literature report of 43 new cases. Rhinology 2000;38:97-101 
5 Yamaguchi KT, Shapshay SM, Incze JS, Vaughan CW, Strong MS. Inverted papillomas and squamous cell carcinoma. J Otolaryngol 1979;8:171-8

6 Vrabec DP. The inverted Schneiderian papilloma: a clinical and pathological study. Laryngoscope 1994;104: 582-605

7 Bielamowicz S, Calcaterra TC, Watson D. Inverting papilloma of the head and neck: the UCLA update. Otolaryngol Head Neck Surg 1993;109:71-6

8 Calcaterra TC, Thompson JW, Paglia DE. Inverting papillomas of the nose and paranasal sinuses. Laryngoscope 1980;90:53-60

9 Baruah P, Deka RC. Endoscopic management of inverted papillomas of the nose and paranasal sinuses. Ear Nose Throat J 2003;82:317-20

10 Kraft M, Simmen D, Kaufmann T, Holzmann D. Longterm results of endonasal sinus surgery in sinonasal papillomas. Laryngoscope 2003;113:1541-7

11 Tomenzoli D, Castelnuovo P, Pagella F, Berlucchi M Pianta L, Delu G et al. Different endoscopic surgical strategies in the management of inverted papilloma of the sinonasal tract: experience with 47 patients. Laryngoscope 2004;114:193-200

12 Lesperance MM, Esclamado RM. Squamous cell carcinoma arising in inverted papilloma. Laryngoscope 1995; 105:178-83

13 Christensen WN, Smith RR. Schneiderian papillomas: a clinicopathologic study of 67 cases. Hum Pathol 1986;17: 393-400

14 Snyder RN, Perzin KH. Papillomatosis of nasal cavity and paranasal sinuses. Cancer 1972;30:668-90

15 Hyams V. Papillomas of the nasal cavity and paranasal sinuses: a clinicopathological study of 315 cases. Ann Otol Rhinol Laryngol 1971;80:192-206

16 Lawson W, Ho BT, Shaari CM, Biller HF. Inverted papilloma: a report of 112 cases. Laryngoscope 1995;105: 282-9

17 Yoon JH, Kim CH, Choi EC. Treatment outcomes of primary and recurrent inverted papilloma: an analysis of 96 cases. J Laryngol Otol 2002;116:699-702

18 Waitz G, Wigand ME. Results of endoscopic sinus surgery for the treatment of inverted papilloma. Laryngoscope 1992;102:917-22

19 Suh K, Facer GW, Devine KD, Weiland LH, Zujko RD. Inverting papilloma of the nose and paranasal sinuses. Laryngoscope 1977;87:35-46

20 Weissler MC, Montgomery WW, Turner PA, Montgomery SK, Joseph MP. Inverted papilloma. Ann Otol Rhinol Laryngol 1986;95:215-21

21 Kaufman MR, Brandwein MS, Lawson W. Sinonasal papillomas: clinicopathologic review of 40 patients with inverted and oncocytic Schneiderian papillomas. Laryngoscope 2002; 121:1372-7

22 Pelausa EO, Fortier MAG. Schneiderian papilloma of the nose and paranasal sinuses: the University of Ottowa experience. J Otolaryngol 1992;21:9-15

23 Benninger MS, Lavartu P, Levine H, Tucker HM. Conservation surgery for inverted papillomas. Head Neck 1991;13: 442-5

24 Myers EN, Fernau JL, Johnson JT, Tabet JC, Barnes EL. Management of inverted papilloma. Laryngoscope 1990; 100:481-90

25 Outzen KE, Grontved A, Jorgensen K, Clausen PP. Inverted papilloma of the nose and paranasal sinuses: a study of 67 patients. Clin Otolaryngol 1991;16:309-12

26 Jardine AH, Davies GR, Birchall MA. Recurrence and malignant degeneration of 89 cases of inverted papilloma diagnosed in a non-tertiary referral population between 1975 and 1995: clinical predictors and p53 studies. Clin Otolaryngol 2000;25:363-9

27 Nielsen PL, Buchwald C, Nielsen LH, Tos M. Inverted papilloma of the nasal cavity: pathological aspects in a follow-up study. Laryngoscope 1991;101:1094-101

28 Nachtigal D, Yoskovitch A, Frenkiel S, Braverman I, Rochon L. Unique characteristics of malignant Schneiderian papilloma. Otolaryngol Head Neck Surg 1999;121:766-71

29 Raveh E, Feinmesser R, Shpitzer T, Yaniv E, Segal K. Inverted papilloma of the nose and paranasal sinuses: a study of 56 cases and review of the literature. Isr $J$ Med Sci 1996;32:1163-7

30 Abildgaard-Jensen J, Greisen O. Inverted papillomas of the nose and paranasal sinuses. Clin Otolaryngol 1985;10: $135-43$

31 Barnes L, Bedetti C. Oncocytic Schneiderian papilloma: a reappraisal of cylindrical cell papilloma of the sinonasal tract. Hum Pathol 1984;15:344-51

32 Buchwald CV, Larsen AS. Endoscopic surgery of inverted papillomas under image guidance - a prospective study of 42 consecutive cases at a Danish university clinic. Otolaryngol Head Neck Surg 2005;132:602-7

33 Buchwald C, Franzmann M-B, Tos M. Sinonasal papillomas: a report of 82 cases in Copenhagen county, including a longitudinal epidemiological and clinical study. Laryngoscope 1995; 105:72-9

34 Chee LWJ, Sethi DS. The endoscopic management of sinonasal inverted papillomas. Clin Otolaryngol 1999;24: 61-6

35 Cummings CW, Goodman ML. Inverted papilloma of the nose and paranasal sinuses. Arch Otolaryngol 1970;92: 445-9

36 Dolgin SR, Zaveri VD, Casiano RR, Maniglia AJ. Different options for treatment of inverting papilloma of the nose and paranasal sinuses: a report of 41 cases. Laryngoscope 2000; 102:231-6

37 Eavey RD. Inverted papilloma of the nose and paranasal sinuses in childhood and adolescence. Laryngoscope 1985;95:17-23

38 Eggers G, Eggers H, Sander N, Kossling F, Chilla R. Histological features and malignant transformation of inverted papilloma. Eur Arch Otorhinolaryngol 2005;262:263-8

39 Furuta Y, Shinohara T, Sano K, Nagashima K, Inone K, Tanaka K et al. Molecular pathologic study of HPV infection in IP and SCC of the nasal cavities and paranasal sinuses. Laryngoscope 1991;101:79-85

40 Hwang CS, Yang HS, Hong MK. Detection of human papilloma virus (HPV) in sinonasal inverted papillomas using polymerase chain reaction (PCR). Am J Rhinol 1998;12:363-6

41 Ingle R, Jennings TA, Goodman ML, Pilch BZ, Bergman S, Ross JS. CD44 expression in sinonasal inverted papillomas and associated squamous cell carcinoma. Am J Clin Pathol 1998;109:309-14

42 Kamel RH. Transnasal endoscopic medial maxillectomy in inverted papilloma. Laryngoscope 1995;105:847-53

43 Kaza S, Capasso R, Casiano RR. Endoscopic resection of inverted papilloma. Am J Rhinol 2003;17:185-90

44 Kelly JH, Joseph M, Carroll E, Goodman ML, Pilch BZ, Levinson RM et al. Inverted papilloma of the nasal septum. Arch Otolaryngol 1980;106:767-71

45 Klimek T, Atai E, Schubert M, Glanz H. Inverted papilloma of the nasal cavity and paranasal sinuses: clinical data, surgical strategy and recurrence rates. Acta Otolaryngol 2000;120:267-72

46 Kristensen S, Vorre P, Elbrond O, Sogaard H. Nasal Schneiderian papillomas: a study of 83 cases. Clin Otolaryngol 1985;10:125-34

47 Lasser A, Rothfeld PR, Shapiro RS. Epithelial papilloma and SCC of the nasal cavity and paranasal sinuses: a clinicopathological study. Cancer 1976;38:2503-10

48 Llorente JL, Dezeyiannis F, Rodrigo JP, Nunez F, Ablanedo P, Melon S et al. Minimally invasive treatment of the nasal inverted papilloma. Am J Rhinol 2003;17: $335-41$

49 Lund VJ. Optimum management of inverted papilloma. J Laryngol Otol 2000;114:194-7

50 Majumdar B, Beck S. Inverted papilloma of the nose. Some aspects of aetiology. J Laryngol Otol 1984;98:467-70

51 McCary WS, Gross CW, Reibel JF, Cantrell RW. Preliminary report: endoscopic versus external surgery in the management of IP. Laryngoscope 1994;104:415-19

52 Mickelson SA, Nichols RD. Denker rhinotomy for inverted papilloma of the nose and paranasal sinuses. Henry Ford Hosp Med J 1990;38:21-4

53 Mirza N, Nofsinger YC, Kroger H, Sato Y, Furth EE, Montone KT. Apoptosis and p53 in inverting papilloma of the sinonasal tract. Am J Rhinol 1999;13:427-34 
54 Momose KJ, Weber AL, Goodman M, MacMillan AS, Roberson GH. Radiological aspects of inverted papilloma. Radiology 1980;134:73-9

55 Norris HJ. Papillary lesions of the nasal cavity and paranasal sinuses. Part 1: exophytic (squamous) papillomas. A study of 28 cases. Laryngoscope 1962;72:1784-97

56 Oberman HA. Papillomas of the nose and paranasal sinuses. Am J Clin Pathol 1964:42:245-58

57 Orvidas LJ, Lewis JE, Olsen KD, Weiner JS. Intranasal verrucous carcinoma: relationship to inverting papilloma and human papillomavirus. Laryngoscope 1999:109:371-5

58 Phillips PP, Gustafson RO, Facer GW. The clinical behaviour of inverting papilloma of the nose and paranasal sinuses: report of 112 cases and review of the literature. Laryngoscope 1990;100:463-9

59 Ridolfi RL, Lieberman PH, Erlandson RA, Moore OS. Schneiderian papillomas: a clinicopathological study of 30 cases. Am J Surg Pathol 1977;1:43-53

60 Schlosser RJ, Mason JC, Gross CW. Aggressive endoscopic resection of inverted papilloma: an update. Otolaryngol Head Neck Surg 2001;125:49-53

61 Segal K, Atar E, Mor C, Har-El G, Sidi J. Inverting papilloma of the nose and paranasal sinuses. Laryngoscope 1986;96:394-8

62 Smith O, Gullane PJ. Inverting papilloma of the nose: analysis of 48 cases. $J$ Otolaryngol 1987;16:154-6

63 Stankiewicz JA, Girgis SJ. Endoscopic surgical treatment of nasal and paranasal sinus inverted papilloma. Otolaryngol Head Neck Surg 1993;109:988-95

64 Terzakis G, Vlachou S, Kyrmizakis D, Helidonis E. The management of sinonasal inverted papilloma: our experience. Rhinology 2002;40:28-33
65 Thorp MA, Oyarzabal-Amigo MF, du Plessis JH, Sellars SL. Inverted papilloma: a review of 53 cases. Laryngoscope 2001; 111:1401-5

66 Tufano RP, Thaler E, Lanza D, Goldberg AN, Kennedy DW. Endoscopic management of sinonasal inverted papilloma. Am J Rhinol 1999;13:423-6

67 Weiner JS, Sherris D, Kasperbauer J, Lewis J, Li H, Persing D. Relationship of human papillomavirus to Schneiderian papillomas. Laryngoscope 1999;109:21-6

68 Woodson GE, Robbins KT, Michaels L. Inverted papilloma: considerations in treatment. Arch Otolaryngol 1985;111:806-11

69 Wormald PJ, Ooi E, van Hasselt CA, Nair S. Endoscopic removal of sinonasal inverted papilloma including endoscopic medial maxillectomy. Laryngoscope 2003;113: $867-73$

Address for correspondence:

Professor N S Jones,

Department of Otorhinolaryngology - Head \& Neck Surgery, Queen's Medical Centre,

University Hospital,

Nottingham NG7 2UH, UK.

E-mail: nick.jones@nottingham.ac.uk

Professor N S Jones takes responsibility for the integrity of the content of the paper.

Competing interests: None declared 